\title{
Judges and Representatives of the People: a Polish Perspective
}

\author{
Małgorzata Gersdorf* and Mateusz Pilich**†
}

The means used to cause revolutions of constitutions are sometimes force and sometimes fraud. Force is employed either when the revolutionary leaders exert compulsion immediately from the start or later on - as indeed the mode of using fraud is also twofold: sometimes the revolutionaries after completely deceiving the people at the first stage alter the constitution with their consent, but then at a later stage retain their hold on it by force against the people's will [...].

Aristotle, Politics ${ }^{1}$

Relations between the judiciary and the elected authorities (i.e. the legislative and the executive) in each country and at all times are among the most sensitive from the point of view of statehood. There is an obvious truth expressed in the famous saying of Lord Acton: 'Power tends to corrupt, absolute power corrupts

*Full Professor of Labor Law at the Faculty of Law and Administration, University of Warsaw, Poland; Chief Justice of the Supreme Court of the Republic of Poland (2014-2020); ORCID No. 0000-0001-7856-4613; e-mail: m.gersdorf@wpia.uw.edu.pl.

**Professor Associate of Private International Law at the Faculty of Law and Administration, University of Warsaw, Poland; Member of the Research and Analyses Office of the S.C.; ORCID No.0000-0001-7934-1606; e-mail: m.pilich@wpia.uw.edu.pl.

${ }^{\dagger}$ Abbreviations index: CT: Constitutional Tribunal (Trybunat Konstytucyjny), Dz.U.: Journal of Laws (Dziennik Ustaw); OSNC: Orzecznictwo Sadu Najwyższego. Izba Cywilna [Supreme Court Reports. Civil Chamber], OSNK: Orzecznictwo Sądu Najwyższego. Izba Karna [Supreme Court Reports. Criminal Chamber], SAC: Supreme Administrative Court (Naczelny Sad Administracyjny), SC: Supreme Court (Sad Najwyższy).

${ }^{1}$ Book V, 31304 b, 〈http://data.perseus.org/citations/urn:cts:greekLit:tlg0086.tlg035.perseuseng1:5.1304b $\rangle$, visited 25 September 2020.

European Constitutional Law Review, 16: 345-378, 2020

(C) The Author(s), 2020. Published by Cambridge University Press on behalf of European Constitutional Law Review. This is an Open Access article, distributed under the terms of the Creative Commons Attribution licence (http://creativecommons.org/licenses/by/4.0/), which permits unrestricted re-use, distribution, and reproduction in any medium, provided the original work is properly cited. doi:10.1017/S1574019620000206 
absolutely'2 ${ }^{2}$ The universal calling of judges is to restrain executive and legislative branches of government in their efforts to increase their power, especially at the expense of individuals. A state where there is no sufficiently strong counterweight to the natural omnipotence of the people's representatives is not in line with the principle of the rule of law, because there is no one to remind the elected powers that their mandate has its limits - contemporarily established in particular by constitutional norms and the international regime for the protection of human rights. ${ }^{3}$ Naturally, courts do not directly take part in a political discourse, even though some kind of judicial review of the acts of public authorities exists virtually everywhere; these should not be characterised as an interference in political matters. ${ }^{4}$ The mutual respect of the judiciary and elected authorities proves the maturity of the state constitutional system, regardless of how far-reaching the powers are of judges to examine the constitutionality of legislation.

Unfortunately, only rarely in history have Polish judges had the opportunity to be treated as an important element of the state system. The country, revived in 1918 after more than a century of domination by three foreign powers, has not been fortunate enough to calmly develop its legal system during the $20^{\text {th }}$ century. In the common mind, administration of justice and law enforcement have always been associated with either foreign rule (German, Austrian and Russian throughout the $19^{\text {th }}$ and early $20^{\text {th }}$ centuries) $)^{5}$ or more or less authoritarian regimes before and after World War II, in which the judiciary was not truly independent. It is not

${ }^{2}$ Lord Acton's letter to Archbishop Mandell Creighton, dated 5 April 1887, 〈https://oll. libertyfund.org/titles/acton-acton-creighton-correspondence\#lf1524_label_010 $\rangle$, visited 25 September 2020.

${ }^{3}$ The retired judge of the Israeli Supreme Court Aharon Barak rightly contends that 'the separation of powers is not a value in itself. It is not designed to ensure efficiency. The purpose of separation of powers is to strengthen freedom and prevent the concentration of power in the hands of one governmental actor in a manner likely to harm the freedom of the individual': A. Barak, The Judge in a Democracy (Princeton University Press 2006) p. 35.

${ }^{4}$ The political power of the courts, derived from the superiority of the Constitution, has justly been remarked on by A. de Tocqueville, Democracy in America, transl. J.T. Schleifer, ed. E. Nolla, vol. 1 (Liberty Fund 2012) 〈https://oll.libertyfund.org/titles/2735〉, visited 25 September 2020, p. $118 \mathrm{ff}$.

${ }^{5}$ Rarely has the judicial profession been truly appreciated in Polish society. During the partitioning of Poland by Russia, Austria, and Prussia (Germany), which lasted from the second half of the $18^{\text {th }}$ century until 1914 , members of the native Polish population were appointed as magistrates practically only in the Austrian part (where there were also German Austrian magistrates). In both the Russian and German parts of Polish territories in the $19^{\text {th }}$ century there were virtually no Polish judges (with a single exception in the Russian lower courts). Together with imposed codes of law (as the old Polish law was practically abandoned), this led to the courts constantly being viewed by the populace as something odd, suspect, and barely understandable. 
difficult to guess that the period under communist rule had the most serious influence on the general public's perception of the judiciary. The epithet of 'communist judge' is still being used as a rhetorical figure, even if it has little to do with reality 30 years after the beginning of the political transformation. ${ }^{6}$

Old clichés, combined with modern means of social influence, greatly facilitate the government's attacks on judges and courts, based, inter alia, on claims that they are detached from reality, corrupt, subject to undisclosed influences and that they neglect the interests of individuals. The beginning of the negative trend can be pinpointed to the year 2015 and double elections, presidential and parliamentary, which provided full power to the candidates of the coalition of three radical-right parties led by Law and Justice. ${ }^{7}$ This victory was treated by the ruling camp as giving them a mandate for radical changes, which have not necessarily been carried out within a framework of constitutional authorisation. Even though the Polish Constitution and the state system have not changed in terms of the supreme law of the land, the top organs of the judiciary have been hollowed out internally: this was primarily due to the court-packing and the deepening ideologisation of legal life. In the current state of affairs, the Polish Constitutional Court and the National Council of the Judiciary have become façades and no longer play their usual roles. They participate in an organised system of pressure on judges.

The example of Poland, compared to other countries that have happened to undergo severe democratic crises, is unusual, as it shows the radical and widespread disagreement and resistance of legal circles to the destruction of structures of the democratic state ruled by law. Significantly, the voice of protest comes from within the Polish judiciary - it is the voice of the judges themselves, and mainly of those of the common courts, as they are under the greatest pressure to subordinate themselves completely to political authorities. ${ }^{8}$ Judges who belong to several associations, currently amounting to approximately $40 \%$ of their total number, publish opinions on draft Bills, teach lessons on the Constitution in schools, take part

${ }^{6}$ See the text to $\mathrm{n} .75$ below.

${ }^{7}$ Since 2015 the governing coalition 'United Right' (Zjednoczona Prawica) has a slight majority of 235 out of 460 seats in the lower house (Sejm); $c f\langle$ https://parlament2015.pkw.gov.pl/〉, 〈https:// sejmsenat2019.pkw.gov.pl/sejmsenat2019/〉, visited 25 September 2020.

${ }^{8}$ See e.g. Amnesty International, Poland: Free Courts, Free People. Judges Standing for Their Independence, (Amnesty International 2019); Amnesty International, Poland 2019: The State of the Judiciary (Amnesty International 2019), 〈https://www.amnesty.org/download/Documents/ EUR3714032019ENGLISH.PDF〉, visited 25 September 2020; J. Kościerzyński (ed.), Justice under pressure - repressions as a means of attempting to take control over the judiciary and the prosecution in Poland. Years 2015-2019 (Polish Judges' Association 'Iustitia'- 'Lex Super Omnia' Association of Prosecutors 2020) 〈https://www.iustitia.pl/images/pliki/raport2020/Raport_EN.pdf), visited 25 September 2020. 
in demonstrations, organise open mock trials, etc. in order to ensure that the protests are heard not only in Poland but also abroad. These forms of social participation are both new and difficult to accept for the political bodies, who try to counteract them mostly through the use of disciplinary measures. In spite of the government's actions, judges believe that their more active and continuous participation in the public debate is necessary in order to educate Polish society. The overall situation can be considered quite unique in the region, where judicial resistance has rarely been encountered on such a massive scale. ${ }^{9}$

Strangely enough, rank and file judges would have many reasons to regard resistance to so-called reforms of the judiciary as ill-advised from their point of view: first is the risk of disciplinary accountability, controlled by the Minister of Justice. Second, the institutional state façade in Poland has so far been kept almost intact and the reforms have mainly affected the higher judicial organs, such as the Constitutional Tribunal and the Supreme Court. Pro-authoritarian reforms have been taking place gradually: court-packing has replaced any idea of rash purges. Citizens more easily adapt themselves to changes that adversely affect their rights and freedoms when the institutional appearance of the status quo is maintained. ${ }^{10}$ Still, there is a widely-shared conviction that the role of the judiciary in an emerging 'prerogative state' ${ }^{11}$ will not be safe: sooner or later, the lawyers will

${ }^{9}$ See, for instance in Hungary, where judges' protests against government interventions were relatively weak, at least until the open conflicts began between the newly established - and parliamentary majority-controlled - National Judicial Office (Országos Bírósági Hivatal Elnöke, OBH) and an old National Judicial Council (Országos Birósági Tanacs, OBT), the latter being one of the basic institutions of judicial self-government. One of the most spectacular events was the stepping down of five members and twelve substitute members of the OBT, allegedly forced by the $\mathrm{OBH}$ and court presidents subject to it. The mission undertaken by the European Association of Judges (EAJ) in April 2019 established other worrying facts, such as a drastic drop-off of public financing of the Association of Hungarian Judges (Magyar Bírói Egyesület, MABIE). However, unlike in Poland, Hungarian judges have not been positioned by the government as a political enemy, thus reasons for a widespread protest might - so far - have been perceived as questionable; $c f S$. Gass et al., Subcommittee of the EAJ Working Group on the Situation in Member Associations: Report on the fact-finding mission of the EAJ to Hungary, 3 May 2019, 〈https:/www.iaj-uim.org/iuw/wp-content/ uploads/2019/05/Report-on-the-fact-finding-mission-of-a-delegation-of-the-EAJ-to-Hungary.pdf), visited 25 September 2020.

${ }^{10}$ H.P. Graver, Judges Against Justice. On Judges When the Rule of Law is Under Attack (Springer 2015) p. $35 \mathrm{ff}$.

${ }^{11}$ The concept of a 'prerogative state' was developed by Ernst Fraenkel in order to explain the nature of the Nazi dictatorship. As the author indicates, 'the political sphere is a vacuum as far as law is concerned. Of course it contains a certain element of factual order and predictability but only in so far as there is a certain regularity and predictability in the behavior of officials. There is, however, no legal regulation of the official bodies. [...] There are no legal rules governing the political sphere. It is regulated by arbitrary measures (Massnabmen), in which the dominant officials exercise their discretionary prerogatives. Hence the expression "Prerogative State" 
be expected to share and support government policies, as well as to foster the supremacy of the values decreed as 'fundamental for the nation'. ${ }^{12}$ Maintaining substantive judicial independence can be expensive. Threats to the exercise of judicial functions are becoming real, especially in an era of low dispute-resolution culture and the manipulation of societal moods through social media, as well as the widely demonstrated lack of respect for state institutions. ${ }^{13}$ Judges have realised that there is a constant need to fight for their legitimacy. The example of Turkey indicates what the cost of negligence can be. ${ }^{14}$

This article is structured as follows. The next section briefly summarises the problem of the independence of judges and courts from the perspective of both the Polish Constitution and international law; it questions the argument that state sovereignty enables the political majority to impose unlimited change on the judicial system, since such an assumption would contradict Poland's international obligations. The following sections show how the decline of constitutional review in and after 2015 contributed to the disintegration of the discursive community of law. Still, legal changes alone do not give a full view of the current state of affairs. The deliberate and systematically waged war against the judiciary has put Polish judges in a hopeless position: whether they like it or not, they are drawn into political life by being blatantly deprived of their credibility with the public. This strategy of the Polish government highlights the need for a debate about the sources of legitimising the third power, included in the final part of this article. Unfortunately, discussion of this topic in Poland has been sidelined for years, which has resulted in a huge deficit of knowledge and understanding of the functions of judges and courts in society. This certainly does not make it any easier for judges to reclaim their individual independence, as well as the independence of the judiciary as a whole, although it can also be seen as a chance for more serious self-reflection.

(Massnahmenstaat)': E. Fraenkel, The Dual State: A Contribution to the Theory of Dictatorship, transl. E.A. Shils (Oxford University Press 2017) p. 3. The other side of the coin is the so-called 'normative state', standing for the sphere of individuals' everyday life, still subject to either the traditionally prevailing or the newly enacted law: ibid., p. 57. Both 'states' build up a 'dual state', where the law gives way to, and may not overrule, political orders.

${ }^{12} C f$ the interview of a German broadcaster and media publisher 'Deutsche Welle' (DW) with the current Prime Minister of Poland, Mateusz Morawiecki, the latter stating that '[o]f course the law is not the most important. The life of people and security is': see A.S. Brändlin, 'Mateusz Morawiecki: EU “completely misunderstood the situation"', 〈https://www.dw.com/en/mateuszmorawiecki-eu-completely-misunderstood-the-situation/a-37547967〉, visited 25 September 2020.

${ }^{13} C f$ J. Clifford Wallace, 'An Essay on Independence of the Judiciary: Independence from What and Why', 58 New York University Annual Survey of American Law (2001-2003.2) p. 241 at p. 245.

${ }^{14} \mathrm{Cf}$ inter alia E. Özbudun, Pending Challenges in Turkey's Judiciary (Istanbul Policy CenterSabanci University-Stiftung Mercator Initiative 2015) (http://www.iai.it/en/pubblicazioni/ pending-challenges-turkeys-judiciary $\rangle$, visited 25 September 2020. 
The main thesis of this contribution is that it is not in every country and under every political circumstance that the form of judges' participation in public discourse can be limited to only typical judicial activities. The democratic crisis in Poland reveals a dramatic need for judges as educators and members of society to be active also outside the courtroom. Otherwise, it might not be possible to bolster the level of social confidence in the judiciary, and thus to strengthen its legitimacy, which has never been high and has been further reduced in recent years, mostly as a result of the progressing global socio-political crisis, which manifests itself in Poland and other Eastern European countries in a return to authoritarianism. A well-expressed but firm opposition to limitations placed on the constitutional competences of the judiciary by political authorities - the latter claiming to have the necessary democratic mandate - is not a form of political activity that is prohibited for judges, but is rather one of the legitimate instruments of participation in the debate. Even more than that, it is a manifestation of the judges' implementation of their mandate towards the nation, which has constituted the judiciary as one of the authorities by which to express its will.

\section{A QUESTION OF JUDICIAL INDEPENDENCE IN THE LIGHT OF DOMESTIC AND INTERNATIONAL LAW}

Ubi societas ibi ius ${ }^{15}$; every human society is governed by law, but law does not necessarily means the same thing everywhere, and it is not treated with an equal dose of respect in every state. It is a truism to say that only law provides procedures for the bloodless distribution and transfer of power; the historical development of Western socio-political culture has proved that it must bind not only the ruled, but also - and primarily - those who hold the power: hence, the evolution of the rule of law as a meta-principle of both domestic and international legal systems.

Regarding the content of constitutional norms, the Republic of Poland undoubtedly declares respect for the rule of law in a sense close to the German idea of the 'Rechtsstaat' (Article 2 of the Constitution of the Republic of Poland ${ }^{16}$ ). It obliges all public authorities to strictly respect the limits of their

\footnotetext{
${ }^{15}$ Variously attributed to Cicero, Ulpian, Hugo Grotius, or Baron Heinrich von Cocceji. The phrase derives from a philosophical argument, inspired by Aristotle's Nicomachean Ethics, usually summarised in a form of the following sylogism: 'Where the human being is, there is a society. Where there is a society, there is law. Therefore: where the human being is, there is law': F.J. Garcia, 'Between Cosmopolis and Community: The Emerging Basis for Global Justice', 46(1) International Law and Politics (2013) p. 1 at p. 1 fn. 1.

${ }^{16}$ Full text available at $\langle$ https://www.sejm.gov.pl/prawo/konst/angielski/kon1.htm $\rangle$, visited 25 September 2020.
} 
competences (Article 7), at the same time establishing solid foundations for the principle of the separation of powers (Article 10). The Constitution can be directly applied by all courts and authorities (Article 8), while constitutional review is entrusted to a special body, called the Constitutional Tribunal, characterised by Polish fundamental law as one of the judicial bodies (Article 188). ${ }^{17}$

It is significant from the point of view of the Polish dispute over the status of the third power that there exists a general constitutional obligation to comply with international law (Article 9), as well as an express supremacy of ratified international treaties and secondary law of the EU (Article 91). From this point of view, the Polish government, which by citing the Constitution ostentatiously underestimates the importance of numerous interventions of international and European institutions in defence of the independence of the judiciary from other authorities, may have a big problem with the credibility of its position, at least in external relations.

While completing the necessary review of the provisions of the Polish Constitution, we must also mention the constitutional framework for the role of judge. Courts and tribunals are defined in the Constitution as a separate authority from the others, whose sole function is the administration of justice (Articles 173 and 175(1)). The exposed political position of judges, who are subject only to the Constitution and statutory law in exercising of their duties, correlates with this legal rule (Article 178(1)). Consequently, judges cannot accept any orders or suggestions regarding the content of their judgments. On the other hand, their independence also has an obvious price: a significant limitation of judges' public activity outside the office they hold (Article 178(3)). Disputes over the extent of the judges' commitment to silence on 'political' matters cast a shadow over attempts to debate newly introduced judicial reforms. Polish law does not accept the term of office of judicial offices at any level: judges are generally appointed for life by the President of the Republic of Poland at the request of the National Council of the Judiciary (Article 179). The latter is a mixed body, but with a predominance of judges (Article 187(1)); in the literature, as well as in the jurisprudence of the

\footnotetext{
${ }^{17}$ Whether or not the Tribunal should be viewed as the only state organ competent to carry out constitutional review used to be one of the most debatable issues in Polish academia. Some Polish authors allowed the refusal to apply legal provisions contrary to the Constitution, which would bring the Polish model of constitutional control closer to the American judicial review, although this standpoint has so far not gained the support of the majority: see R. Hauser and J. Trzciński, 'O formach kontroli konstytucyjności prawa przez sądy', 52(2) Ruch Prawniczy, Ekonomiczny i Socjologiczny (2008) p. 9; cf W. Kręcisz, 'Stanowisko sądów powszechnych wobec bezpośredniego stosowania Konstytucji RP', in K. Działocha (ed.), Bezpośrednie stosowanie Konstytucji Rzeczypospolitej Polskiej (Warszawa 2005) p. 114.
} 
Constitutional Tribunal before 2015, there was a well-established view that 15 judges to the Council should be elected by their peers. ${ }^{18}$

The struggle for the judicial independence in Poland has contributed much to the internationalisation and Europeanisation of the debate over the issue. Although the doctrine of the rule of law has been evolving gradually over many centuries, and it still does not have uniform content in various nation states, it is possible to point out its common core. First of all, it contains equality before the law; second, division and separation of branches of government, which stresses the independence of judiciary. ${ }^{19}$ The preservation of the system based on the rule of law is today virtually an unquestionable duty of states, explicitly enshrined in numerous acts of international law and thus constituting one of the general principles of the jus gentium. ${ }^{20}$ One

\footnotetext{
${ }^{18}$ See e.g. T. Ereciński, 'Pozycja ustrojowa Krajowej Rady Sądownictwa', in A. Dębiński et al. (eds.), Ius et lex: ksiega jubileuszowa ku czci Profesora Adama Strzembosza (Katolicki Uniwersytet Lubelski 2002) p. 266; L. Garlicki, in Konstytucja Rzeczypospolitej Polskiej. Komentarz, vol. IV (Wydawnictwo Sejmowe 2005) Art. 187 No. 3; M. Jabłoński, 'Uwagi o ewolucji gwarancji niezawisłości i niezależności sędziów i sądów powszechnych', in J. Trzciński and B. Banaszak (eds.), Studia nad prawem konstytucyjnym, Acta Universitatis Wratislaviensis. Prawo CCLVII (Uniwersytet Wrocławski 1997) p. 124-125; D. Górecki et al., Polskie prawo konstytucyjne, $4^{\text {th }}$ edn. (Wolters Kluwer Polska 2012) p. 219; H. Zięba-Załucka, Władza ustawodawcza, wykonawcza i sadownicza w Konstytucji Rzeczypospolitej Polskiej (LexisNexis 2002) p. 295-297; CT judgment of 18 July 2007, case No. K 25/07, OTK-A 2007, No. 7, item 80.

${ }^{19} \mathrm{D}$. von der Pfordten, 'On the foundations of the Rule of Law and the Principle of the Legal State/Rechtsstaat', in J.R. Silkenat et al. (eds.), The Legal Doctrines of the Rule of Law and the Legal State (Rechtsstaat) (Springer 2014) p. 15 ff; M. Loughlin, The rule of law in European jurisprudence, Venice Commission Study 512/2009, CLD-DEM(2009)006, 〈https://www.venice.coe.int/ webforms/documents/default.aspx?pdffile=CDL-DEM(2009)006-e $\rangle$, visited 25 September 2020, with further reference to other sources.

${ }^{20}$ There are, to be sure, doubts about the exact scope of respect for the rule of law among contemporary members of the international community. Some authors tend to believe that the community of elementary values and principles constituting the rule of law may be considered to include only Western states, while other states either by definition reject or modify it according to their own perceptions of the role and place of law; $c f$ R. Gosalbo-Bono, 'The Significance of the Rule of Law and Its Implications for the European Union and the United States', 72 University of Pittsburgh Law Review (2010) p. 229 at p. 288-290. It should be noted, however, that the rule of law is recognised in a number of contemporary international treaties, not necessarily 'Western' ones, e.g. Art. 14(1) of the UN International Covenant on Civil and Political Rights (signed and ratified by 172 states), UNTS 999, 171; 1057, 407; see N. Kaufman Hevener and S.A. Mosher, 'General Principles of Law and the UN Covenant on Civil and Political Rights', 27(3) International and Comparative Law Quarterly (1978) p. 596 at p. 610; $c f$ also Art. 2(2)(h) of the ASEAN Charter, UNTS 2624, 223; on the international rule of law, see inter alia K.J. Keith, 'The International Rule of Law', 28(3) Leiden Journal of International Law (2015) p. 403, 〈https://doi.org/10.1017/S0922156515000199〉, visited 25 September 2020, A. Watts, 'The International Rule of Law', 36 German Yearbook of International Law (1993) p. 15; J. Crawford, 'International Law and the Rule of Law', 24 Adelaide Law Review (2003) p. 3.
} 
might be tempted to declare a universal obligation on this basis, in the sense of an obligation of customary international law (consuetudo). Without the rule of law, it would be difficult to imagine the peaceful cooperation of states ready to guarantee to their citizens the enjoyment of a minimum of rights in the globalised world, thus realising their individual freedom to establish cross-border legal relations, which are so necessary in the field of trade and everyday human life. ${ }^{21}$

Forcing reforms that reduce the independence of the judiciary in countries drifting away from constitutional democracy is often supported by the contention that the state is sovereign and has the right to decide freely about the organisation of its authorities. Is it a just argument? Of course, the international recognition of the rule of law as one of the general principles of law limits the margin of discretion of the state when it comes to establishing, interpreting, and applying internal law. Even if the international community today is not competent to impose on any government the concept or interpretation of its internal legal order in accordance with the requirements derived from the 'core' of the rule of law (and, as a consequence, there are states disregarding this principle), it is precisely because of a widespread international concept of the rule of law that the basic standards of the states' behaviour can be set. Furthermore, it is thanks to this that sanctions against members of the international community for violating the necessary minimum guarantees for individuals in this respect have become possible at all. ${ }^{22}$ The arguments of national authorities against international interventions in the defence of the rule of law based on the traditional considerations of the state sovereignty and the will of the majority cannot be found as justified.

\footnotetext{
${ }^{21}$ Cf K. Kuźmicz, 'The Kantian model of the state under the rule of law', 19 Studies in Logic, Grammar and Rhetoric (2009) p. 13 at p. 30. Immanuel Kant's very idea of 'perpetual peace', based on the peaceful federation of states (foedus pacificum) whose constitutions establish a 'republican rule' seems to be heading in this direction. Kant seemed to understand this as, first and foremost, a guarantee of the minimum freedom of individuals and their formal equality before the law, and this irrespective of the concrete form of government; moreover, these rights were to be universally recognised in all the states concerned. Equal guarantees of the rights and freedoms of individuals everywhere create a 'cosmopolitan right' (hospitalitas), which is - figuratively speaking - their right to be free and equally treated everywhere, enforceable against any sovereign: see I. Kant, Perpetual Peace and Other Essays (Hackett Publishing 1983) p. $107 \mathrm{ff}$.

${ }^{22}$ At the international level, such sanctions are dispersed and relative in nature (stronger only in the field of the law of international organisations): see M. Pilich, 'The Rule of Law from the Perspective of International Law', in Studia i Analizy Sąu Najwyższego. Materiaty naukowe. T. VIII: Przysztośc Europy opartej na rzadach prawa/The Future of Europe Based on the Rule of Law (Sąd Najwyższy 2019) p. 125 at p. 136-137, 151.
} 


\section{THE CREEPING DEATH OF CONSTITUTIONAL REVIEW}

From the legal point of view, the increasingly dramatic position of Polish judges towards authority derived from popular elections has its source in these two constitutional issues: the subordination of courts to the Constitution and statutes; and judges' obligation to maintain restraint - not to carry out public activities that cannot be reconciled with the principles of independence of courts and judges. The example of Poland shows that the questions asked by philosophers long ago have not become outdated: can a judge be allowed to engage in public debate and openly protest when political authorities, in the name of an alleged democratic mandate, violate the constitutional status of her office? Is she obliged to comply with every law only because it was adopted by a representative body?

The first act in the drama of the Polish judiciary was the total loss of independence and authority of the Constitutional Tribunal. It is worth reminding those not immersed in Polish current affairs that it was the first victim of the transformation of the Polish system after the 2015 elections. Without attempting to describe in detail the whole battle, which resulted in a paralysis of the functioning of the Tribunal, and then its takeover by persons clearly associated with the ruling camp ${ }^{23}$, it is enough to say that the course of events confirms the lack of ordinary respect for the law and its extreme instrumentalisation. Over the past five years, the ruling camp has not shied away from pushing through important systemic draft Bills on the organisation of constitutional review and the judiciary in just a few days and without any consultation. ${ }^{24}$ The membership of the Constitutional Tribunal was determined by ordinary parliamentary resolutions, which annulled the previous valid elections of judges. 'Undesirable' judgments of the Constitutional Tribunal regarding the newly enacted laws on the organisation of constitutional control were ignored for as long as necessary from the

\footnotetext{
${ }^{23}$ The general outline of the Polish Constitutional Court's decay has been reported in English, inter alia, by Wojciech Sadurski and Marcin Matczak; see W. Sadurski, Poland's Constitutional Breakdown (Oxford University Press 2019) p. 58 ff; M. Matczak, Poland's Constitutional Crisis: Facts and Interpretations (FLJS 2018) 〈https://www.fljs.org/content/poland\%E2\%80\%99sconstitutional-crisis-facts-and-interpretations $\rangle$, visited 25 September 2020. For important data and analyses from the initial period of 2015-2016, see P. Radziewicz and P. Tuleja (eds.), Konstytucyjny spór o granice zmian organizacji $i$ zasad działania Trybunatu Konstytucyjnego (2017) (only in Polish).

${ }^{24}$ The whole procedure in the matter of a Draft Bill on the Amendment of the Act on Constitutional Tribunal (Parliamentary Document No. 12) lasted only six days until the final voting: see 〈http://www.sejm.gov.pl/Sejm8.nsf/PrzebiegProc.xsp?nr=12〉. The 'debate' on another important draft Bill on the Amendment of the same Act (Parliamentary Document No. 122) took just a week: see 〈http://www.sejm.gov.pl/Sejm8.nsf/PrzebiegProc.xsp?nr=122〉, both links in Polish, visited 25 September 2020.
} 
government's point of view. ${ }^{25}$ Meanwhile, the persons elected as constitutional judges by the votes of the ruling coalition publicly demonstrated their loyalty to the government. ${ }^{26}$ In the end, the Constitutional Tribunal, in matters of key importance to the government, became merely a means of transmitting political will to the area of law. Composed of people mostly deprived of authority and in-depth legal knowledge, accepting open manipulation as regards the course of pending cases ${ }^{27}$, it mainly serves the function of creating the appearance of democratic constitutionalism and restraining the legal community from questioning the new order. ${ }^{28}$

The facts indicated above, although far from a comprehensive description of reality, allow us to formulate a well-founded thesis that at present the

${ }^{25}$ See judgments: of 9 March 2016, K 47/15, Dz.U. 2018, Item 1077, OTK 2016/A/2; of 11 August 2016, K 39/16, Dz.U. 2018, Item 1078, OTK 2016/A/71; of 7 November 2016, K 44/16, Dz.U. 2018, Item 1079, OTK 2016/A/86. All these rulings were promulgated in the Journal of Laws reluctantly, under the pressure of the EU, after a very long time, and with an unprecedented government annotation that the judgments were issued 'in violation of the provisions of the Act' and concerned 'a normative act that had lost its binding force.'

${ }^{26}$ See e.g. a statement by Professor Lech Morawski during the symposium at the University of Oxford on 9 May 2017, where he openly admitted that was is acting not only on behalf of the President of the Constitutional Tribunal, but also the government; 'An Oxford symposium on the Polish constitutional crisis sparks public debate', 12 May 2017, 〈https://www.law.ox.ac.uk/ news/2017-05-11-oxford-symposium-polish-constitutional-crisis-sparks-public-debate $\rangle$, visited 25 September 2020. The President of the Tribunal, Julia Przyłębska, was described by the political leader of the governing camp, Jarosław Kaczyński, in a press interview as his 'great social discovery', which quite clearly indicates the close relationship between them: 'Mam wielu przyjaciół w polityce i poza nią, 13 May 2019, 〈https://www.tvp.info/42604906/mam-wielu-przyjaciol-w-polityce-i-pozania), visited 25 September 2020.

${ }^{27}$ The most flagrant abuse was the exclusion of three 'old' judges from adjudication under the pretext of the challenge to their mandate by the Prosecutor General-Minister of Justice Zbigniew Ziobro. The challenge, incidentally, remained unheard until the end of their term of office: M Kryszkiewicz, 'Podwójne standardy w TK. Składy zależne od woli Zbigniewa Ziobry', 〈https://prawo.gazetaprawna.pl/artykuly/1078563, podwojne-standardy-w-tk-wylaczenie-sedziow. html $\rangle$, visited 10 September 2020.

${ }^{28}$ As in the case of an interference in the course of ongoing court proceedings against high-ranking Law and Justice politicians managing the Central Anti-Corruption Bureau, Mariusz Kamiński and Maciej Wąsik, pardoned by the President of the Republic before the final conviction. The adoption in 2017 by the Supreme Court of a resolution explaining the effects of exercising the right of pardon by the President for pending criminal proceedings resulted in a very quick submission by the Speaker of the Sejm of an application for settlement of an alleged competence dispute between the President of the Republic of Poland and the Supreme Court. Thanks to this trick, the political majority managed to suspend the proceedings in the case of those pending before the Supreme Court (which is still pending due to the Tribunal's failure to resolve the application); see the case before the CT, application No. Kpt $1 / 17$, documents available at $\langle$ https://trybunal.gov.pl/s/kpt-117〉; Supreme Court ruling of 1 August 2017, II KK 313/16, unpublished, available at 〈http://www.sn. $\mathrm{pl} /\rangle$ (both in Polish, visited 25 September 2020). 
Constitutional Tribunal no longer exists in practice and cannot be a partner in the dialogue between the courts and the body competent in matters of constitutional review. The situation can be compared to some extent with the case of Dollfussian Austria, in which the Constitutional Tribunal fell victim to the political machinations of the federal government in $1933 .{ }^{29}$ Of course, it could be argued that the situation of Poland after 2015 and Austria after 1933 is incomparable in all respects: Poland is not a state in a deep socio-economic crisis, nor is there any serious political actor pushing through the program of abolishing parliamentarism, suspending the Constitution, as well as civil rights or the rule of law. However, putting aside direct analogies, in both cases one can notice the ostentatious lack of respect for the law as an intrinsic value, and the same will to subordinate independent institutions to the current political majority, so that power is to be concentrated - in an absolutely undemocratic way - in one hand.

\section{POlish JUdGeS AND THE TRAP OF 'Illiberal Legalism': POlitical pressure on the JUdiciary in Poland, 2015-2020}

The fall of constitutional review is closely linked to the condition of the judiciary as a whole. This is not only because there is no buffer between the courts and the legislative authority, which is naturally a constitutional court. The fate of the latter concentrates, as through a lens, the negative attitude of the government and its parliamentary majority towards all independent institutions, and indicates the direction in which the entire Polish third power is heading.

The authoritarian modus operandi of political authorities can be observed in several areas, including the reform of the Law on the Prosecutor's Office of $2016^{30}$, which resulted in an absolute power of the Prosecutor GeneralMinister of Justice. The principle of equality of arms of the prosecutor and the accused, which is the basic premise of a fair trial, has become a fiction more than

\footnotetext{
${ }^{29}$ The resignation of the speaker of the pre-war Austrian parliament (Nationalrat) and his two deputies became a pretext for suspending the work of the legislative body and the taking over of its functions by the government. It was the most important step towards dictatorship. Soon thereafter, seven members of the Constitutional Tribunal (Verfassungsgerichtshof) resigned of their office in exchange for a likely promise from the federal government that they would be appointed judges of a replacement body - the Federal Tribunal (only three of them were actually appointed). The other judges did not form a quorum capable of hearing the case that caused the executive to take this action. They just accepted their fate, without even trying to challenge the legal provision which had led to this stalemate situation: K. Heller, Der Verfassungsgerichtshof: Die Entwicklung der Verfassungsgerichtsbarkeit in Österreich von den Anfängen bis zur Gegenwart (Verlag Österreich 2010) p. $251 \mathrm{ff}$.

${ }^{30}$ Law of 28 January 2016 on the Prosecution Office (ustawa $z$ dnia 28 stycznia 2016 r. o prokuraturze), consolidated text: Dz. U. of 2019 Item 740.
} 
ever in Poland's recent history (i.e. since 1989). This fact presented a challenge to the intra-EU principle of mutual trust between systems of justice and, as a consequence, became the reason for disturbing the intra-EU extradition procedure on the basis of the European Arrest Warrant. ${ }^{31}$

Even more bitter for the Polish lawyers' community, the judicial self-government that was formed as a result of the political transformation has practically ceased to exist. The pro-democratic reforms initiated in 1989-1990, including the setting up of the National Council of the Judiciary, as well as of judicial self-government bodies in the strict sense (above all assemblies of judges at particular levels of the judiciary $)^{32}$, are being undone; in a sense, therefore, the situation in the judiciary is returning to the state of affairs at the end of the Polish People's Republic. It results from a change of its model, which is gradual and thus imperceptible to many observers. Meanwhile, the impact of the executive on the judges and courts has been increasingly strong: as evidenced among others in the opinions of the renowned international bodies ${ }^{33}$, both courts' management ${ }^{34}$ and the composition of the Council, whose judicial members are now elected by the parliament

${ }^{31}$ ECJ 25 July 2018, C-216/18 PPU, LM, ECLI:EU:C:2018:586.

${ }^{32} \mathrm{~K}$. Grajewski, 'Postulat utworzenia rady do spraw sądownictwa podczas obrad Okragłego Stołu', 10(3) Krajowa Rada Sadownictwa (2017) p. 25 at p. 25-26; A. Śledzińska-Simon, 'The Rise and Fall of Judicial Self-Government in Poland: On Judicial Reform Reversing Democratic Transition', 19(7) German Law Journal (2018) p. 1839 at p. 1841-1842.

${ }^{33}$ European Commission For Democracy through Law (Venice Commission), Poland: Opinion No. 904/2017 On the Draft Act Amending the Act On the National Council of The Judiciary, On the Draft Act Amending The Act On the Supreme Court, Proposed By the President of Poland, And On the Act On the Organisation of Ordinary Courts, 11 December 2017, p. 5-7, 〈http://www.venice.coe.int/ webforms/documents/default.aspx?pdffile $=\mathrm{CDL}-\mathrm{AD}(2017) 031-\mathrm{e}\rangle$, visited 25 September 2020; Commission Recommendation (EU) 2017/1520 of 26 July 2017 regarding the rule of law in Poland complementary to Recommendations (EU) 2016/1374 and (EU) 2017/146 (OJ L 228, 2.9.2017, p. 19) paras. 26-28, 45; Commission Recommendation (EU) 2018/103 of 20 December 2017 regarding the rule of law in Poland complementary to Recommendations (EU) 2016/1374, (EU) 2017/146 and (EU) 2017/1520 (OJ L 17, 23.1.2018, p. 50) paras. $27 \mathrm{ff}$; UN Human Rights Council, Report of the Special Rapporteur on the independence of judges and lawyers on his mission to Poland, 05.04.2018, A/HRC/38/38/Add.1, 〈https://documents-dds-ny.un.org/doc/ UNDOC/GEN/G18/084/27/pdf/G1808427.pdf?OpenElement $\rangle$, visited 25 September 2020.

${ }^{34}$ Pursuant to the 2017 transitional provisions, the Minister of Justice, acting alone and without any justification, decided to replace about one-fifth of court presidents and vice-presidents; the decisions taken were at least controversial, as some of the appointees were e.g. disciplinarily convicted or their competence and authority in the professional environment could be doubted (e.g. one of the appointees 52 times unsuccessfully applied for the post of judge, but her achievements were negatively assessed by the National Council of the Judiciary); B. Grabowska-Moroz and M. Szuleka, Od kadr się zaczyna. Zmiana prezesów i wiceprezesów sadów powszechnych w okresie od sierpnia 2017 r. do lutego 2018 r. [It begins with the staff. Change of presidents and vice presidents of common courts in the period from August 2017 to February 2018] (Helsińska Fundacja Praw Człowieka 2018) 〈http://www.hfhr.pl/ wp-content/uploads/2018/04/HFPC-Od-kadr-sie-zaczyna.pdf), s. 21, visited 10 September 2020. 
and not by their peers ${ }^{35}$, comprised the candidatures in various ways associated with the Ministry of Justice or directly dependent on him due to their functions. In fact, the courts' presidents and vice presidents are fully dependent upon the will of the Minister, who freely decides on the amount of service allowances to be granted to them and was endowed with a virtually free prerogative to decide on their appointment and dismissal. The former, in turn, have enormous powers vis-à-vis judges, deciding on their professional status and being able to demand disciplinary proceedings, as well as managing the organisational structure of courts (appointing and dismissing presidents of the courts divisions). ${ }^{36}$ Generally speaking, the new organisational frameworks of the Polish judiciary are not only filled with politically lenient staff and operate according to non-transparent criteria ${ }^{37}$, but what is worse, they dramatically reduce the sphere of independent decision-making by particular judges, who must not forget what the specific consequences of their rulings may be. ${ }^{38}$

The extremely negative impact of legislative changes on the functioning of the Polish Supreme Court is the last issue that we need to summarise briefly. The history of the political dispute around the Supreme Court and the establishment of new, controversial chambers (Disciplinary and Extraordinary Control and

\footnotetext{
${ }^{35}$ In total, 12 out of 18 judicial candidates for the current Council were connected in various ways with the Ministry and the current Minister of Justice, and these ones actually were accepted by the Sejm; see the data summary on the SSP Iustitia website, /https://www.iustitia.pl/nowa-krs/2102kandydaci-do-krs-i-ich-pelnomocnicy (in Polish), visited 25 September 2020. In January 2020, during the debate in the Senate on the so-called 'Muzzle Act', the Minister of Justice-Prosecutor General, Zbigniew Ziobro, openly admitted that the parliamentary majority personally shaped the National Council of the Judiciary in such a way as to obtain the desired political effect: 'We submitted candidatures of such judges who in our opinion were ready to cooperate within the framework of the reform of the judiciary'; M. Wilgocki, “"Myśmy zgłosili”. Ziobro przypadkiem zdradził, kto poparł sędziów do KRS?', 〈https://wyborcza.pl/7,75398,25603501,mysmy-zglosiliziobro-przypadkiem-zdradzil-co-jest-na-utajnionych.html $\rangle$, visited 25 September 2020.

${ }^{36}$ Śledzińska-Simon, supra n. 32, p. 1846, 1856.

${ }^{37}$ The non-transparency of the elections of the National Judiciary Council has a particular importance in this respect. For a long time it was not possible to verify the lists of support for candidates. Evidence disclosed at the beginning of 2020 showed that, among others, one of the members of the new Council did not obtain the required number of 25 valid signatures of the judges supporting him, and in several other cases the signatures could be put in blank by the group of the same judges delegated to the Ministry of Justice. The Council was therefore composed even in violation of such a defective law as that adopted by the Sejm: A. Łukaszewicz, Listy poparcia do KRS sq jawne - co z nich wynika, 16 February 2020, 〈https://www.rp.pl/Sedziowie-i-sady/ 302169946-Listy-poparcia-do-KRS-sa-jawne-co-z-nich-wynika.html〉; M. Jałoszewski, Iustitia: Listy do KRS poparli niemal wytacznie beneficjenci rzadów PiS. Publikujemy peten wykaz, 〈https:// oko.press/iustitia-listy-do-krs-poparli-niemal-wylacznie-beneficjenci-dobrej-zmiany-pis/ $\rangle$, visited 25 September 2020.

${ }^{38}$ See inter alia Supreme Court, Opinion No. BSA I/II-021-161/17 of 28 April 2017, available at 〈http://www.sejm.gov.pl/Sejm8.nsf/druk.xsp?nr=1491〉, in Polish, visited 25 September 2020.
} 
Public Affairs) is quite well known from the case law and literature. ${ }^{39}$ It seems, however, that the devastating impact of the reforms from the perspective of the national judge has not yet been fully realised. Meanwhile, there are, first, legal provisions that clearly limit the jurisdiction of the courts ${ }^{40}$, which places the legislative and executive powers clearly above the judiciary, quite in contradiction to the concept of the division of branches of government. Due to the political control over the judiciary, it is no longer possible to officially question the rationale of such provisions by submitting applications to the Constitutional Tribunal, which leads to the adoption of a kind of 'forced presumption of constitutionality'. Second, due to the specific instrument of the control over judgments of the common courts introduced in 2018 - viz the extraordinary complaint - the case law of the newly created Extraordinary Control Chamber has started to create divergences with the 'old' Chambers of the Supreme Court; thus the lower courts are facing a real problem about the hierarchy of authority in adjudicating. ${ }^{41}$ Eventually the courts have found themselves in a maze of conflicting hierarchies.

In the literature, such a situation is sometimes referred to as 'autocratic legalism'. It is a state of affairs in which both democratic mandate and legal means are abused to implement the undemocratic political agenda; in other words, a democratically elected leader commits a coordinated and constant attack on institutions whose function is to control his actions, and on regulations that set the basis for his responsibility, even if he or she does so in the name of his democratic mandate. ${ }^{42}$ As can be seen from the above description, the key part of these efforts is the takeover of independent institutions - that is, in principle, the judiciary - by court-packing. First of all, constitutional courts are taken over, in the course of

\footnotetext{
${ }^{39}$ See ECJ 19 November 2019, Joined Cases C-585/18, C-624/18 and C-625/18, A.K. and others, ECLI:EU:C:2019:982; F. Zoll and L. Wortham, 'Judicial Independence and Accountability: Withstanding Political Stress in Poland', 42(3) Fordham International Law Journal (2019) p. 875.

${ }^{40}$ The so-called 'Muzzle Act' aims at preventing the courts, including the Supreme Court, from using an interpretation of the principle of independence in line with European and international law. First of all, it provides for the prohibition of challenging the judicial mandate of any person sworn in by the President as judge and orders the commencement of disciplinary proceedings against judges who in any way - official or not -question the composition of the court with the participation of such persons. The Act, which has been in force since 14 February 2020, in principle provides for two types of sanctions: transfer to another place of service; or dismissal of a judge from office: see Act of 20 December 2019 Amending the Act - Law On The Structure of Common Courts, The Act On the Supreme Court and Some Other Acts, Dz. U. 2020 Item 190.

${ }^{41} \mathrm{~T}$. Zembrzuski, 'Extraordinary complaint in civil proceedings under the Polish law', 2(1) Access to Justice in Eastern Europe (2019) p. 31, 〈https://doi.org/10.33327/AJEE-18-2.1-a000006〉, visited 25 September 2020.

${ }^{42}$ K.L. Scheppele, 'Autocratic Legalism', 85 The University of Chicago Law Review (2018) p. 545 at p. 548-549.
} 
which the nomination procedures are changed or the manner of performing their functions is modified. ${ }^{43}$

However, as usually happens with definitions in social sciences, they rely on considerable simplifications. This is easily seen by comparing the Polish and Hungarian situations. In the case of Hungary, Viktor Orbán's Fidesz has continuously had a constitutional mandate since 2010, which strengthens the formal legitimacy of legal changes, even if some of the seats in the last two elections $(2014,2018)$ have been won by the party due to manipulation of the electoral law and the unequal conditions of the campaign for opposition parties. The most controversial reforms are introduced in a way that has knocked the courts out of any arguments against the application of laws enacted by parliament. In this arrangement, even the jurisprudence of the Hungarian Constitutional Court may possibly be transformed by an Act of parliament acting as the constitutive assembly: if necessary, the content in question is simply introduced into the Fundamental Law, which ends any debate on the validity of any resolution. ${ }^{44}$ It is difficult for a judge, who by nature must be a legalist, to question the formally valid result of lawmaking.

We believe that Polish judges are in a much more difficult situation than their Hungarian colleagues - in a place where escape into a convenient option of submitting to the will of political power is virtually impossible without compromising the oath. This is a position between the Scylla of allegiance to the binding Constitution and the Charybdis of observance of the Acts adopted by the majority in parliament, which may well infringe the Constitution, while there is no possibility of verifying this hypothesis. Article 178(1) of the Constitution does not help in finding a way between these two options. By treating their function seriously, i.e. by acting in accordance with the Constitution, e.g. through proconstitutional reinterpretation of provisions or the application of prevailing provisions of international and European law, judges are in real danger of being subject to disciplinary and even criminal liability, which in the conditions of the struggle for full power is and will be increasingly enforced. ${ }^{45}$ In turn, trying to

${ }^{43}$ T. Drinóczi and A. Bień-Kacała, 'Illiberal Constitutionalism: The Case of Hungary and Poland', 20 German Law Journal (2019) p. 1140 at p. 1146.

${ }^{44}$ Ibid., pp. 1152, 1155-1156.

${ }^{45}$ The recent disciplinary prosecution of several judges who referred questions to the CJEU could serve as an example, as for instance the case of Ms. A. Bator-Ciesielska, a judge of the Regional Court (Sad Okregowy) in Warsaw; see Justice under pressure, supra n. 8, p. 14 ff. As to the criminal liability, there have also been attempts to prosecute judges for specific decisions they made as part of their judicial activity; cf A. Zadworny, Prokuratura wzywa na przestuchania sędziów, którzy nie chcieli aresztować prezesów ZCh Police, 16 March 2018, 〈https://szczecin.wyborcza.pl/szczecin/ 7,34939,23150183, prokuratura-wzywa-na-przesluchania-sedziow-ktorzy-nie-chcieli.html $\rangle$, visited 25 September 2020. 
please the rulers and enforce all the regulations without looking at their compliance with the Constitution, in accordance with the principle so criticised by Gustav Radbruch that 'an order is an order' and 'a law is a law ${ }^{46}$, judges do not fulfil their obligations towards society, thus deepening mistrust of the third authority. They cannot count on the Constitutional Tribunal because its existence, paradoxically, does not currently serve to ensure compliance of the law with higher legal rules; the purpose of this institution, as a result of the changes made, is actually to discourage judges from asking whether there is any inconsistency of ordinary laws with the Constitution.

Although the last thesis might at first glance look unconvincing (why should the government take control over the Constitutional Tribunal in order to turn it off?), it seems to be confirmed in the light of all available data. If the Polish constitutional court were to actually serve to shift the legal discourse in Poland to the side of the ruling camp and thus create a strong basis for the legitimacy of the new, autocratic system, it should first of all perform its usual role. However, statistics are inexorable: in 2014, the Constitutional Tribunal received a total of 530 cases, and in 2015 a record number of 623 cases, in 2017 the number dropped to 282 cases. The decrease in the number of legal questions submitted by the courts in cases pending before them is very telling: in 2015, 135 such cases were submitted to the Court, while in 2017 there were only $21 .{ }^{47}$ The negative trend is therefore more than proportional to the decrease in the overall number of cases. More recent data is difficult to access because the Court has stopped the annual publication of its activity reports. However, even based on the data available on the Constitutional Tribunal website, it can be concluded that nothing has changed for better.

It could of course be argued that the actual decrease in the significance of the Constitutional Tribunal results from the decisions of the judges themselves (or other entities authorised to initiate proceedings before the Constitutional Tribunal) not to present constitutional issues due to the subjective dislike of this body in its current composition, which from a purely legal point of view should not matter. It is not difficult to prove, however, that the decision to submit a question does not guarantee that an answer will be obtained, especially when the subject of the case is not in line with the political expectations of the ruling camp.

As an example of such an approach, one could give the matter of the act sanctioning the service of uniformed officers for the benefit of a totalitarian state;

\footnotetext{
${ }^{46} \mathrm{G}$. Radbruch, 'Statutory Lawlessness and Supra-Statutory Law' (transl. B. Litschewski Paulson and S.L. Paulson), 26(1) Oxford Journal of Legal Studies (2006) p. 1 esp. p. 6: 'Positivism, with its principle that "a law is a law", has in fact rendered the German legal profession defenceless against statutes that are arbitrary and criminal. Positivism is, moreover, in and of itself wholly incapable of establishing the validity of statutes'.

${ }^{47}$ B. Szepietowska, 'Działalność orzecznicza Trybunału Konstytucyjnego w latach 2014-2017', in Funkcjonowanie Trybunału Konstytucyjnego w latach 2014-2017 (Fundacja Batorego 2018) p. 19-20.
} 
it radically reduced the retirement benefits for all persons who served for any period of time in units belonging to the supporters of the Polish People's Republic (regardless of the nature of such service, as well as the positive result of verification after the turn of 1990 and service in free Poland). The constitutional question regarding the Act was submitted by the District Court in Warsaw at the end of January 2018 in connection with the case before it. The date of the hearing was set only recently, after numerous prompts from the courts and other entities (the Ombudsman), for whom the issue is a priority: there are circa 24,000 such instances in the Polish courts, and they mostly concern older people for whom the right to obtain a judgment within a reasonable time is of particular importance. However, whether and when the proceedings before the Constitutional Tribunal will end, is not known. ${ }^{48}$ The decision does not suit those in power, who treat the reviewed legislative act as a kind of historical justice: settlement with communism, despite the awareness that collective responsibility is simply unfair. For these reasons, it is not surprising that, waiting in vain for a swift judgment in an important case, some courts resumed proceedings and handed down judgments without looking at the Constitutional Court. ${ }^{49}$ Judges who might still have had any doubts about the legitimacy of questioning the role of the Constitutional Tribunal will certainly not forget this lesson.

\section{CUIUS REGIO, EIUS INTERPRETATIO, OR THE DISRUPTION OF THE DISCURSIVE LEGAL COMMUNITY}

In the model of centralised constitutional review based on the Kelsenian doctrine $e^{50}$, the dialogue between the courts and the constitutional court, as well as thorough legislative proceedings is fundamental to building a discursive legal

\footnotetext{
${ }^{48} \mathrm{P}$. Rojek-Socha, 17 marca TK zajmie się tzw. ustawa dezubekizacyjna, 06 February 2020, 〈https:/www.prawo.pl/prawnicy-sady/ustawa-dezubekizacyjna-termin-rozprawy-w-tk,497751.html〉, visited 25 September 2020; the current date of handing down the judgment in the case No. P 4/18, set out after several postponements, is 6 October 2020; see 〈https://trybunal.gov. $\mathrm{pl} / \mathrm{s} / \mathrm{p}-418\rangle$, visited 29 September 2020 .

${ }^{49}$ Recently, the Court of Appeal in Warsaw ordered the District Court to consider the cases of retired officers affected by the Act of 16 December 2016 without further waiting for the judgment in Case P 4/18. It is argued that there is a right to a fair trial that cannot be put off indefinitely. Furthermore, the way the Constitutional Tribunal operates has raised doubts in the Warsaw Court of Appeal, which indicates to the subordinate court that it has the Constitution at its disposal and can directly apply it: P. Nowosielska, Ustawa dezubekizacyjna. Sądy apelacyjne nie czekaja na TK, 20 January 2020, 〈https://serwisy.gazetaprawna.pl/praca-i-kariera/artykuly/1449335, ustawadezubekizacyjna-wyroki-sadow-apelacyjnych.html $\rangle$, visited 25 September 2020.

${ }^{50} \mathrm{H}$. Kelsen, Wesen und Entwicklung der Staatsgerichtsbarkeit. Überprüfung von Verwaltungsakten durch die ordentlichen Gerichte (1929); idem, Wer soll der Hüter der Verfassung sein?, $2^{\text {nd }}$ edn (Tübingen 2019).
} 
community. Adopting the concept of discourse in the sense given to this concept by Jürgen Habermas and Robert Alexy ${ }^{51}$, we are of the opinion that law in modern society cannot be seen as a dictate of the current parliamentary majority. The law as a discourse is subordinated to certain idealising assumptions: the participating parties should be able to assume that they mean the same thing by the same words and expressions, should consider themselves as rationally accountable, and be able to suppose that when they arrive to a mutually acceptable resolution, supporting arguments sufficiently justify a (defeasible) confidence that any claims to truth, justice, etc. that underlie their consensus will not later turn out to be false or mistaken. $^{52}$

In the discursive concept of law, which is close to our beliefs, the rationality of law results from the exchange of positions and from the development of solutions that are universally acceptable. As Habermas rightly puts it, the majority decision must be premised on a competent discussion of the disputed issues, that is, on a discussion conducted according to the communicative presuppositions of a corresponding discourse. Only then can its content be seen as a rationally motivated but fallible result of the process of argumentation that has been interrupted in view of institutional pressures to decide, but in principle is resumable. Habermas believes that doubts as to the legitimacy of majority decisions in cases of irreversible consequences are revealing in this regard. The outlawed minority give their consent to the empowerment of the majority only with the proviso that they themselves retain the opportunity in the future of winning over the majority with better arguments, and thus of revising the previous decision. ${ }^{53}$

As can be seen from the background of the facts cited above, the process of legislating and controlling its constitutionality in Poland does not meet the conditions of rationally conducted discourse. Courts cannot assume that the same words and concepts - viz. not only for the courts, but also for the parliament and the constitutional court dominated by the political majority - are understood in the same way and that such terms are consistent with common consensus. The meaning of constitutional concepts is freely modified in such a way that reflects the current aspirations of the ruling parties and their current tactics of political struggle; the final goal seems to be to consolidate the changes made in the institutional and personal dimension.

${ }^{51}$ J. Habermas, Between Facts and Norms. Contributions to a Discourse Theory of Law and Democracy, transl. W. Rehg (The MIT Press 1996); R. Alexy, A Theory of Legal Argumentation: The Theory of Rational Discourse as Theory of Legal Justification, trans. R. Adler and N. MacCormick (Clarendon Press 1989).

${ }^{52}$ For a summary of basic assumptions of the discourse in Habermas's philosophical system, see L. Morawski, Główne problemy wspótczesnej filozofii prawa. Prawo w toku przemian, wyd. 1 (PWN 1999) p. 107-108, with further references.

${ }^{53}$ Habermas, supra n. 51, p. 179. 
An example of this kind of concept modification is the principle of democracy, which the parliamentary majority supporting the government understands as equivalent to the politicising of all state institutions, including the courts. Rhetorically, the matter would be about bringing about a state in which all these institutions would allegedly be subjected to the actual control of the nation as a sovereign. Apart from the argument that the people also may be a tyrant $\mathrm{t}^{54}$, with this assumption it is impossible to talk about the functioning of the principles of the judicial independence enshrined in the Constitution at an acceptable level from the point of view of the Polish constitutionalism. ${ }^{55}$ The Constitution expresses the principle of democracy limited by the separation of powers and guarantees of individual rights and freedoms. The parliament does not have any superior position over judicial power, and even more so it does not carry out control over the judiciary. Thus, the growing party control of the entire apparatus of power means the disappearance of the actual separation of powers, in which the judiciary, separated from representative authorities, performs its function of control and restraint. ${ }^{56}$

In recent years, the implementation of the program of 'repairing' the judiciary has significantly taken form far from the theory of discourse. It was disclosed gradually, and only after Law and Justice secured a decisive influence on the Constitutional Tribunal; it somewhat proves the full awareness of the reformers that their actions have not been in line with the current state system. Needless to say, none of the draft Bills mentioned so far have been the subject of consultation with judges; this also concerns the package of presidential projects on the reform of the Supreme Court and the National Council of the Judiciary ${ }^{57}$ adopted in December 2017, despite the fact that they were the result of mass social protests in defence of the court system in the summer of 2017.

The Polish example shows how the courts in a state appropriated by the ruling majority are deprived of the power to decide on the interpretation of applicable

\footnotetext{
${ }^{54}$ See J.S. Mill, On Liberty, $4^{\text {th }}$ edn. (Longmans 1869) p. 12.

${ }^{55}$ It seems that most opinions on legal changes in Poland after 2015 were wrongly limited to examining sources of law (in the broad sense of the word), while the real significance of these changes is hard to comprehend without the political context. Shortly before taking over power, the leader of the ruling party in the coalition Jarosław Kaczyński openly announced his ideas, allegedly justified by placing the will of most citizens in his grouping. The judiciary, as nothing more than an 'intra-state corporation', had to be controlled by the winning political parties in the name of the sovereign; Jarostaw Kaczyński w Klubie Ronina [Jarostaw Kaczyniski in the Ronin's Club] - 08/06/ 2015, 〈http://youtu.be/4c7Y9uyUL7U〉, 5'33"-15'42”, visited 26 September 2020.

${ }^{56}$ R. Piotrowski, 'Sędziowie i granice władzy demokratycznej w świetle Konstytucji RP', 53(1) Ruch Prawniczy, Ekonomiczny i Socjologiczny (2018) p. 215 at p. 216.

${ }^{57}$ See two Acts of 8 December 2017: (i) amending the Act on the National Council of the Judiciary and certain other acts, Dz. U. of 2018, item 3, and (ii) on the Supreme Court, consolidated text: Dz. U. 2019, item 825.
} 
law. Cuius regio eius interpretatio: this paraphrase of the known principle of the Peace of Augsburg ${ }^{58}$ accurately reflects, in our opinion, the desire of the ruling coalition led by the PiS party to adapt the concepts of the legal system in a manner convenient for achieving their goals. The point is to eliminate any positions competing in the discourse, and thus to give oneself the exclusive right to decide what the argument and the reason in the dispute are. As in the times of the Reformation, attributing to the ruler the unilateral determination of the status quo invalidates discourse and breaks the community. Courts in the Republic of Poland cease to be an equal partner in the constant dialogue with the legislator and the Constitutional Tribunal; moreover, as it turns out, their legitimacy for exercising public authority is being undermined. The law subjected to the arbitrary will of the imaginary majority becomes the rule of conduct, regardless of whether it can be rationally argued under the Constitution still in force.

Moving towards a summary of the present part of the analysis of the position of the Polish judiciary in relation to political authorities, it should be emphasised that the term 'autocratic legalism' is apt insofar as it is used as a metaphor describing the destruction of democracy by law, while disregarding the meaning of the term 'legalism' established in the theory of constitutionalism. In fact, at present it would be difficult to define Poland as a 'legalist' state, even within the meaning of the rule 'by law' (viz the formal rule of law), replacing the existing substantive rule of law.

In recent years, Polish legislation has ceased to meet the basic requirements of internal morality according to Lon Fuller's assumptions. ${ }^{59}$ It no longer really creates a framework for social life; the political position of the ruling camp and which is not without significance in Polish conditions - the ad hoc decisions of its top management have the supreme position. If the law does not comply with them, then the state apparatus appropriated by the party is able to get over it by any means. It may be the adoption of a parliamentary Act changing the

\footnotetext{
${ }^{58}$ The slogan cuius regio eius religio (Latin, 'whose land, his religion') was coined early in the 17 th century by the Protestant canon lawyer Joachim Stephani to describe key principle of the Peace of Augsburg of 29 September 1555, which gave the Imperial estates the freedom of deciding between Catholicism (Roman Catholic Church) and Lutheranism (Protestantism; Protestant churches) in their own territories: R. Potz, 'Cuius regio, eius religio', in G. Dunphy and A. Gow (eds.), Encyclopedia of Early Modern History Online (Brill 2015) 〈http://dx.doi.org/10.1163/23520272_emho_SIM_018148>, visited 26 September 2020.

${ }^{59}$ Fuller's concept of the 'internal morality of law', which seems to be universal, has been based on eight principles that proclaim law should be general, publicly promulgated, clear, non-contradictory, possible to comply with, relatively constant through time, non-retroactive, and the official actions should be congruent to a declared rule: L.L. Fuller, The Morality of Law (Yale University Press 1969) p. 41.
} 
applicable law in the course of an ongoing competition procedure ${ }^{60}$; a judgment of the Constitutional Tribunal contrary to the case law established over 25 years, also potentially faulty due to the panel composition ${ }^{61}$; legal opinion containing a position which is isolated and impossible to defend ${ }^{62}$; finally, there may be completely arbitrary action that the political authorities generally do not care for at all. ${ }^{63}$

The courage of judges to issue rulings contrary to the expectations of the party, just 30 years after the fall of communism, has become precious again. This time it is not just because of ideological issues but, first and foremost, due to a lack of respect for the constitutional premises of the separation of the judiciary as one of the state authorities. Treated as an 'intra-state corporation' under the party control, they are too weak to be heard and understood by their fellow citizens. What can be done to avert the crisis?

\section{Deficit of legitimacy: Should the Polish Judges be more PROACTIVE?}

From the very beginning, i.e. since 2015, Polish anti-constitutional populist backsliding was marked by an uncompromising fight with the judiciary. There are many signs showing that it could have been in preparation for a long time, and the next stages of the attack, regardless of temporary changes in tactics, have all been agreed in advance. This is evidenced by both the statements of the leader

\footnotetext{
${ }^{60}$ See two subsequent Acts amending the procedure of appointment of the Supreme Court Justices in the course of an ongoing competition, extinguishing the right to the court: the Act of 20 July 2018 amending the Law on the structure of common courts and some other Acts, Dz.U. of 2018, item 1443; Act of 26 April 2019 amending the Act on the National Council of the Judiciary and the Law on the structure of administrative courts, Dz. U. of 2019 item 914.

${ }^{61}$ See the CT judgment of 20 June 2017, case No. K 5/17, OTK 2017/A/48 (delivered in a panel of only five judges, it sanctioned the derogation from the previous constitutional case law on the election of members of the National Judiciary Council).

${ }^{62} \mathrm{C} f$ the case of an opinion prepared for the governing majority, according to which the election of CT judges in 2015 simply was null and void due to the competence to submit candidatures for judges granted to the Presidium of the Sejm 'and' the group of at least 50 MPs - hence the alleged necessity for joint action of both bodies; $c f \mathrm{M}$. Warciński, Spór o Trybunat: Prezydent nie może przyjąc ślubowania, 9 December 2015, 〈https://www.rp.pl/Opinie/312099994-Spor-o-TrybunalPrezydent-nie-moze-przyjac-slubowania.html $\rangle$, visited 26 September 2020. The literal interpretation of the provision was obviously incorrect, as it only listed the nomination bodies and was far from regulating the election procedure. The opinion's massive criticism, however, did not prevent its author from soon becoming a judge of the Constitutional Tribunal, elected by the Law and Justice deputies.

${ }^{63}$ See the case of non-promulgated (until 2018) judgments of the CT, supra n. 25.
} 
of the ruling camp ${ }^{64}$, as well as by the programming documents of the 'United Right' of summer $2015 .{ }^{65}$ After the first winning elections, the role of the centre coordinating actions directed at courts and judges was taken over by the Minister of Justice - the Prosecutor General together with a group of collaborators, including both politicians and judges delegated to the Ministry of Justice and prosecutors promoted to the National Prosecutor's Office (the highest organisational link in the new hierarchical structure of the prosecutor's office).

Fighting the judiciary in Poland is not only about legal changes. It is a concerted sequence of factual and legal actions of a kind of 'hybrid war.' The tool of the ruling camp is in the first place fierce propaganda, directed at the defamation of the judges' environment, attributing to it dirty intentions and ultimately discouraging citizens from courts and judges. There is no lack of evidence. For the last five years, the term 'extraordinary caste' - as a collective name for judges introduced by some of the top Law and Justice politicians - has become extremely popular in the social media controlled by the ruling camp. It is supposed to suggest that judges violate the law, have complete impunity and do not see their role as a service to society. ${ }^{66}$ The government indirectly inspired and financed (through

${ }^{64}$ During his meeting with voters in the 'Klub Ronina' (supra n. 55), Jarosław Kaczyński openly expressed the opinion (referred to as the general opinion of Polish society) that the courts 'do not exercise their duties..., harm the people ... and sometimes they hand down judgments which are outrageous, just unprecedented'. He also repeated allegations - dismissed, incidentally, by the Prosecutor's Office - of 'corruption at the Supreme Court'. Moreover, Mr Kaczyński ascribed to the entire Supreme Court an intention to fight his political camp, especially due to the case of his close associate, Mariusz Kamiński, allegedly initiated as revenge for the fight to 'clean up the judiciary'. All this made, Kaczyński argued, the change in the judiciary critically necessary.

${ }^{65}$ In July 2015, Janusz Wojciechowski, a current European Commissioner for Agriculture and a former prominent politician of the Law and Justice party, listed certain goals of the 'United Right' electoral program in the field of administration of justice, and among them: (i) the merger of the posts of the Prosecutor General and the Minister of Justice; (ii) enacting an institution of the 'extraordinary appeal'; (iii) introducing lay judges to the higher courts. He, as well as the other speakers (esp. Beata Kempa, a former Deputy Minister of Justice), expressed a high level of distrust in the courts, by calling them a 'State within the State' or an 'absolute power', as well as stirring the public to smash 'the corporate solidarity of the persons exercising the legal professions': see transcripts of speeches by J. Wojciechowski and B. Kempa in Myślac Polska: Konwencja Programowa Prawa $i$ Sprawiedliwości oraz Zjednoczonej Prawicy. Katowice, 3-5 lipca 2015 r. [Thinking Poland: The Program Policy Conference of the Law and Justice and the Allied Right. Katowice, 3-5 July 2015] (the publication of The Alliance of European Conservatives and Reformists [AECR] and PiS), Katowice 2015, 〈http://pis.org.pl/document/archive/download/127〉 p. 151-152, 154, visited 26 September 2020.

${ }^{66}$ See e.g. an interview of the ex-Deputy Minister of Justice, Patryk Jaki, for the public TV broadcaster TVP Info; Problemy sadownictwa to przewlektość i jakość orzecznictwa [Problems of judiciary are the length and quality of judgments], 26 January 2017, 〈http://www.tvp.info/28796106/problemysadownictwa-to-przewleklosc-i-jakosc-orzecznictwa), visited 26 September 2020. This narrative has been reproduced by government TV in the very name of a new program broadcast from the 
a foundation funded by state-owned companies) an outdoor campaign, closely modelled upon the modus operandi of the Hungarian government. ${ }^{67}$ Part of the defamatory actions were undoubtedly also the foreign appearances and publications of the Polish Prime Minister Mateusz Morawiecki, in which the judges were referred to as unrelated collaborators of the communist regime, and were even compared to officers of Vichy France or Francoist Spain. ${ }^{68}$ Obviously, this picture is far from complete, but still it gives some background of the conditions under which the judiciary in Poland is labouring.

The impression of declaring a ruthless war was to be intensified by the creation of the Department of Internal Affairs in the National Prosecutor's Office in March 2016, to which 10 prosecutors were delegated with the sole task of supervising criminal proceedings in matters of judges and prosecutors. So far, it is difficult to say that the allegations of mass corruption among judges have proven to be true. As of September 2018, 110 criminal cases were conducted in the aforementioned Department (generally, causing a road accident or drunk driving and several cases for other acts, including corruption offences); of that number, 61 cases concerned

beginning of 2020 and entitled the 'Caste': Kontrowersyjne wyroki i ludzkie dramaty. Rusza program „Kasta', 20 January 2020, 〈https://www.tvp.info/46280964/kontrowersyjne-wyroki-i-ludzkiedramaty-rusza-program-kasta $\rangle$, visited 26 September 2020. In a popular right-wing Internet newspaper, wpolityce.pl, new articles using this defamatory term are being published practically every day: see e.g. J. Jachowicz, 'Nadzwyczajna kasta' jako perpetuum mobile własnych patologii [The 'extraordinary caste' as a perpetuum mobile of its own pathologies], 11 December 2019, 〈https:// wpolityce.pl/polityka/477276-nadzwyczajna-kasta-perpetuum-mobile-wlasnych-patologii $\rangle$, visited 26 September 2020.

${ }^{67}$ It was called 'Fair Courts', carried out by two PR specialists, permanently employed in the Chancellery of the Prime Minister. The content of billboards and advertising in the social media were alleged offences committed by judges (sometimes fake, in some cases actually disciplined or even committed by deceased persons). The cost of the whole campaign was PLN 8.5 million (circa $€ 2$ million). In 2018, the court in Warsaw found a violation of the articles of association of the Polish National Foundation in financing this undertaking: D. Mazur, 'Sędziowie pod specjalnym nadzorem, czyli 'wielka reforma' wymiaru sprawiedliwości', in Ł. Bojarski et al. (eds.), Konstytucja. Praworzadność. Wtadza sadownicza. Aktualne problem trzeciej władzy w Polsce (Warszawa 2019) p. 261 at p. 268-269; J. Gwizdak, 'Twist in the Legal Universe. Finding a Real European Foundation for the Rule of Law in Poland', 11 February 2020, 〈https:// visegradinsight.eu/twist-in-the-legal-universe/ $\rangle$, last visited 04/04/2020.

${ }^{68} \mathrm{Cf}$ e.g. M. Morawiecki, 'Prime Minister Mateusz Morawiecki: Why my government is reforming Poland's judiciary', Washington Examiner, 13 December 2017, 〈https://www. washingtonexaminer.com/prime-minister-mateusz-morawiecki-why-my-government-is-reformingpolands-judiciary $\rangle$, visited 26 September 2020; 'Poland lobbies EU leaders on investigation into court reforms, Irish Times, 15 December 2017, 〈https:/www.irishtimes.com/news/world/ europe/poland-lobbies-eu-leaders-on-investigation-into-court-reforms-1.3328844 $\rangle$, visited 26 September 2020; 'Polish Prime Minister discusses the state of Europe and Poland with J.H.H. Weiler', NYU Law News, 21 April 2019, 〈https://www.law.nyu.edu/news/Poland-primeminister-morawiecki-weiler-jean-monnet-center $\rangle$, visited 26 September 2020. 
public prosecutors, while only 49 cases related to acts committed by judges. Admittedly, there were some spectacular cases (e.g. an indictment of theft for one of the appellate judges), but this can still be treated as an exception to the rule of their compliance with legal order. ${ }^{69}$

Many Polish lawyers, in the face of such a massive and unprecedented fight, ask themselves what is the reason for it? Can it be defined in legal terms? What can be said on this basis about the condition of the Polish judiciary? Where do we go as a nation?

Historical reasons for the conflict, to which leaders of the government and the supporting parties often return in public appearances ${ }^{70}$, are certainly not insignificant, although they rely on sweeping simplifications. Judges are blamed for participating in communist repression and for lack of self-cleansing after the political breakthrough in 1989-1990. Even though such cases took place, the majority of judges behaved decently, trying to acquit, or at least not to punish, the disobedient. ${ }^{71}$ Of course, some of them did not. ${ }^{72}$ It is hard to deny that settlements with the past were imperfect. Still, the collective name of a 'communist judge' is generally unfair: those involved in communist repression mostly left the judiciary after 1990, undertaking other legal professions or eventually retiring. In the second half of the 1990s, there were also cases of their removal in various procedures (e.g. in disciplinary or lustration proceedings), even if it is true that this did not happen often and quickly. ${ }^{73}$ In 1990, all judges of the Supreme Court underwent a re-appointment procedure involving the newly created National Council of the Judiciary, which resulted in the replacement of about $81 \%$ of the composition of that Court (according to the current state of affairs, all those

\footnotetext{
${ }^{69}$ A. Łukaszewicz, 'Specwydział prokuratury: z wielkiej chmury mały deszcz' [Specialised department of the prosecutor's office: a lot of fuss over nothing], 11 September 2018, 〈https://www.rp.pl/ Prokuratorzy/309109910-Specwydzial-prokuratury-z-wielkiej-chmury-maly-deszcz.html $\rangle$, visited 26 September 2020.

${ }^{70}$ See e.g. Prime Minister Morawiecki, interviewed in NYU News, supra n. 68.

${ }^{71}$ M. Stanowska and A. Strzembosz, Sędziowie warszawscy w czasie próby 1981-1988 (Warszawa 2005) p. 67. Such attitudes may be referred to as the 'rule departures': J. Feinberg, 'Civil Disobedience in the Modern World', in J. Feinberg, Freedom and Fulfillment: Philosophical Essays (Princeton University Press 1992) p. 152.

${ }^{72}$ Ibid., p. 79 ff.

${ }^{73}$ Śledzińska-Simon, supra n. 32, p. 1842-1843. Attempts to prosecute judges in the years 1990-1997 brought very moderate results. Only after 1997 did the amended Law on the System of Common Courts enable the Minister of Justice to apply to the National Council of the Judiciary for bringing accusations against judges who before 1990 misappropriated the judge's oath; out of 47 such cases, 37 judges were subject to financial sanctions, while six were brought before criminal courts (none of the latter cases, however, ended with a final conviction); if Stanowska and Strzembosz, supra n. 71, p. 288-289, 296-297.
} 
appointed for the first time before 1990 have either retired or died).$^{74}$ It would be difficult to expect that those nominated during the existence of the Polish People's Republic - only because of the appointment by the authoritarian state - belonged to the supporters of the Communist regime, and moreover, that they would suddenly refrain from adjudicating and be replaced immediately by new cadres which democratic Poland in 1990 simply did not have. Similarly to the Polish case, the extension of the mandate of judges appointed by the former regime took place in many other countries emerging from undemocratic forms of government, e.g. Spain ${ }^{75}$ and the Federal Republic of Germany. ${ }^{76}$

All in all, justice has been dispensed by time: there has been a natural generational change. The average age of a judge in Poland is currently around 40 years. In the district courts (in Polish: sady rejonowe), which hear most cases as the courts of the lowest tier, the parties usually meet people who completed their legal education at the earliest at the beginning of the 1990s. A higher age of judges in senior courts is quite natural ${ }^{77}$, but all of them have been positively verified

\footnotetext{
${ }^{74}$ Under the Act of 20 December 1989 amending the Law on the structure of common courts, the Act on the Supreme Court, the Act on the Supreme Administrative Court, the Act on the Constitutional Tribunal, the Act on the structure of military courts and the Law on Notaries [ustawa z 20 grudnia 1989 r. o zmianie ustaw - Prawo o ustroju sądów powszechnych, o Sądzie Najwyższym, o Naczelnym Sądzie Administracyjnym, o Trybunale Konstytucyjnym, o ustroju sądów wojskowych i Prawo o notariacie], Dz.U. No. 73, item 436, the five-year term of office of SC judges was abolished, and their irremovability was introduced. The five-year term of office of the Supreme Court at that time was shortened and ended on 30 June 1990 (Article 9 of the Act). The new composition of the Court was appointed by the President of the Republic of Poland on 4 June 1990. A total of 57 judges were appointed to the four chambers, including 22 from the previous composition of the Supreme Court.

${ }^{75}$ J. Urias, 'Spain has a Problem with its Judiciary', verfassunsblog, 15 January 2020, 〈https:// verfassungsblog.de/spain-has-a-problem-with-its-judiciary/>, visited 26 September 2020.

${ }^{76}$ One of the German authors emphasises that German judges were not at all responsible for the crimes of the Nazi state: B. Diestelkamp, 'Die Justiz nach 1945 und ihr Umgang mit der eigenen Vergangenheit', 5 Rechtshistorisches Journal (1986) p. 153 at p. 156. To be sure, after the collapse of the German Democratic Republic the reaction of the apparatus of the newly united Germany was different and making some of the Communist high functionaries accountable was held possible under the guidance of the general principles of the international law. It might, however, be due to the superior position of the West Germany, which as an established democracy was ready to push through the responsibility of the functionaries of the former Eastern German state. Such a situation would have been non-existent in 1945 and for the years of Adenauer's era. Moreover, even the reaction of the German Federal Court of Justice (Bundesgerichtshof) to the offences of some members of the judiciary of the former GDR was assessed as too lenient and, furthermore, only most flagrant cases of ignoring fundamental rights were punished. This example shows that expecting a new regime to sanction all the judges for any slightest offence whatsoever against of human rights and liberties is hardly imaginable in practice: cf Graver, supra n. 10, p. 192-199.

${ }^{77}$ Out of more than 10,000 judges currently adjudicating in common courts, 1,015 (about 10\%) began adjudicating before 4 June 1989 (i.e. before the landmark June elections) as judges or temporary judges. At least 36 judges of the Supreme Court began their careers in common and
} 
by the passage of time since the democratic system was established. Besides, at the end of the Polish People's Republic, today's appellate or Supreme Court judges would at most have occupied junior positions in the judiciary, and the probability that they adjudicated in any political matter is close to zero.

Another contention by Law and Justice and their allies is the alleged alienation of the judiciary and a disregard for the public interest. This argument hardly can be rationalised. The Constitution of the Republic of Poland of 1997 describes the status of the judiciary in a correct way: pursuant to Articles 10 and 173 of the Constitution, it is a separate and independent branch of government charged with the task of the administration of justice, which may not be assigned to any other state body. There is nothing unusual in this formula. Since there are many interconnections between the courts and the political powers in terms of administrational and financial matters and, moreover, judges are bound by the Constitution and statutory law, attempts to claim that judges are above the law and are trying to fight for political power in society are simply incomprehensible. In none of the constitutional regimes of the Western world, to which Poland belongs due to the civilisational choice made at the turn of 1989 and 1990, does the judiciary participate in politics. Logically, a judge, unlike a deputy from an opposition party, cannot be positioned by members of the governing political force as a competitor. By definition alone, as Alexis de Tocqueville has convincingly shown, the judiciary does not engage in a dispute with elected authorities, even by ruling on the responsibility of state agents; after all, the authority of a judge consists in something else: she is to monitor compliance with the law, acting within its limits, and only on the application of an authorised party ${ }^{78}$

Equally false, from a legal point of view, sound the submissions criticising the 'juristocracy' as dangerous to democracy, as well as the lack of the mandate of judges coming from the Nation. We do not question that the importance of the judiciary today is on the rise for various reasons. However, terms such as 'juristocracy' or 'courtocracy' either have a metaphorical sense or - taken literally - do not fit Polish realities. From a general perspective, it seems that the interventions of the judiciary in areas traditionally occupied by representative power are neither desired by the judges nor are a result of their efforts to dominate society. They are rather a side effect of independent phenomena: an increase in the number of legal regulations (so-called 'inflation of the law'), the growing complexity of social life, as well as the

administrative courts before 1989, although the vast majority commenced after the darkest period of martial law (1981-1982). From the current composition of the Supreme Court, 10 judges were appointed to the Supreme Court in the 1990s, 22 in the 2000s, and 69 in the 2010s: 'Ilu sędziów zaczynało orzekanie jeszcze w PRL-u? Sprawdzamy słowa prezydenta', 〈https:// konkret24.tvn24.pl/polityka, 112/ilu-sedziow-zaczynalo-orzekanie-jeszcze-w-prl-u-sprawdzamyslowa-prezydenta,987116.html $\rangle$, visited 26 September 2020.

${ }^{78} \mathrm{C} f$ de Tocqueville, supra n. 4 , p. $117-118$. 
need for judges to create legal rules where the statutory law provision is insufficient. ${ }^{79}$ At the same time, the concept of 'juristocracy' seems to be associated rather with the judicial activism and the creeping takeover of competences of the representative power, rather than with the general development of the jurisdiction of the courts. ${ }^{80}$

Meanwhile, taken against the background of the courts in many other Western countries, the position of Polish courts does not present any threat to representative democracy. Admittedly, the judiciary after 1990 has gained immensely in importance, assuming in its jurisdiction e.g. the validity of elections and referendums, and - with the entry into force of the Constitution of 1997 - obtaining a new right of direct application of the latter (previously unknown). Still, the Polish judiciary as a whole is rather conservative and withdrawn. An extreme positivism, manifested in the cult of the statutory law and its literal interpretation, is only slowly being replaced. Attempts to exercise judicial review of constitutionality, as well as to create new legal rules through a broader interpretation of the law, seem to be rather infrequent and modest. In the light of our observations, accusing Polish judges of attempts to take over part of the power to legislate has no justification on the facts.

The arguments of the Polish government founding its superiority over the judiciary in the fact that, unlike the courts, political powers have a direct support of the voters in the form of universal elections seem also to be mistaken. While it is difficult to deny that the Nation is sovereign (Article 4(1) of the Constitution), it cannot rationally be argued that in order to take up position as a true State authority, the judiciary should derive its mandate directly from the will of the voters. ${ }^{81}$ It is precisely because constitutional democracy rests on the limitation by law of every authority - including the legislative - that the legitimacy ${ }^{82}$ of

${ }^{79}$ Piotrowski, supra n. 56, p. 220-221.

${ }^{80} \mathrm{R}$. Hirschl, Towards Juristocracy: The Origins and Consequences of the New Constitutionalism (Harvard University Press 2004); C. Guarneri and P. Pederzoli, From Democracy to Juristocracy? The Power of Judges: A Comparative Study of Courts and Democracy; C.A. Thomas (ed.) (Oxford University Press 2002); T. Vallinder, 'The Judicialization of Politics. A World-Wide Phenomenon: Introduction', 15(2) International Political Science Review/Revue Internationale De Science Politique (1994) p. 91.

${ }^{81}$ Even though in some countries (as, for instance, the USA or the UK) there are actually exceptions to this rule, consisting in the selection of justices of the peace or magistrates, competent in some minor cases.

${ }^{82}$ The term 'legitimacy' may be defined in two ways, namely either as the set of criteria for the 'validity' of power, i.e. its 'title' for giving commands and demanding obedience, or as the justification of its legality, viz a kind of a special qualification, a surplus to the (pure) force which the state exercises in the name of law. For the sake of the present study, we find the latter understanding appropriate: see H. Gribnau, 'Legitimacy of the Judiciary', in E. Hondius and C. Joustra (eds.), Netherlands Reports to the Sixteenth International Congress of Comparative Law (Intersentia 2002) p. 25. 
judicial power is indirect, relying on duly established and promulgated law. ${ }^{83}$ By the same token, the legitimacy of the judiciary is ensured when a properly elected representative body has established, within the framework of the Constitution, legal rules conferring judicial power on the basis of these legal regulations, and then appropriate persons have been appointed, by the procedures provided for by law, to exercise the power of adjudicating. The demos has appointed independent judges and courts to hear cases pursuant to the Constitution and statutory law (Articles 173 and 178 of the Constitution), in accordance with the rule of law (Article 2), and at the same time it ordered the Constitution to be applied directly as the supreme law of the country (Article 8). Whereas the Constitution includes the principle of separation of powers (Article 10), the demos has the obligation to accept that the courts are duly empowered, within the province of their jurisdiction, to adequately deter representatives of the majority from exceeding their electoral mandate flowing from the system of constitutional norms. The judiciary is therefore a legitimised authority, and judges are also representatives of the Nation within the meaning of Article 4(2) of the Constitution, no less than the members of the legislative are. Furthermore, an additional legitimising factor is precisely that separation of powers, without which representatives of the current majority could do everything, and the concepts of constitution and law would lose all meaning. ${ }^{84}$

The silence of judges and acceptance of the reforms, which distort the Polish constitutional system and undermine the foundations of Poland's participation in the European community of nations, do not help them obtain or strengthen legitimacy. Quite the opposite: such behaviour is a dead end. It potentially leads to a deepening of the phenomenon of social and legal delegitimisation of judicial authority. We appreciate the fact that in the last five years our own awareness of the role of judges in society and their responsibility for the fate of the state has changed radically. Judges have become visible outside the courts.

As already stated, the forms of non-judicial activities of judges are diverse and it would be difficult to list them in detail. It is enough to point out that they include publishing opinions in social and mass media on the condition of the judiciary, and on the changes introduced into the legal system by legislative authority, and pressure exerted on judges and courts by representatives of the executive,

${ }^{83}$ C.D. Classen, Demokratische Legitimation im offenen Rechtsstaat. Zur Beeinflussung des Demokratieprinzips durch Rechtsstaatlichkeit und internationale Offenheit (Tübingen 2009) p. 20; cf J. Kostrubiec, 'Istotna prawnej legitymizacji władzy', 4-5 Studenckie Zeszyty Naukowe (2001) p. 8 at p. $18-19$.

${ }^{84}$ See R.M. Małajny, 'Podział władzy państwowej jako przesłanka jej legitymizacji', 22(3) Przeglad Sejmowy (2014) p. 26-28; cf also the concept of the 'constitutional recapture' by T.T. Koncewicz, 'The Capture of the Polish Constitutional Tribunal and Beyond: Of Institution(s), Fidelities and the Rule of Law in Flux', 43 Review of Central and East European Law (2018) p. 116 at p. 143. 
especially by the Minister of Justice. It should be emphasised that such steps are legally risky, as they provoke the reaction of the Disciplinary Prosecutor of Common Courts and his two deputies, subordinate to the Minister of Justice. For instance, disciplinary proceedings have been commenced against the President of the Association of Polish Judges 'Iustitia', Krystian Markiewicz, due to his public criticism of the activities of the Disciplinary Chamber of the Supreme Court and the re-organised National Council of the Judiciary. Such statements have been found to run counter to the prohibition on judges undertaking any political activity. ${ }^{85}$ Meanwhile, the Constitution does not deprive judges of their right to express opinions, and the absolute restriction on their freedom of speech seems to be manifestly disproportionate to the goal being achieved, all the more so as the freedom of expression of a judge is a well-established standard of the European Convention on Human Rights. ${ }^{86}$

In the context of the issues raised, an interesting case study was a public demonstration organised by the judges' associations together with other nongovernmental organisations, called the 'March of a Thousand Robes'. In order to object to the drafted restrictions on the independence of the judiciary, representatives of the legal professions, including judges, walked in silence through the streets of Warsaw, wearing the costumes they usually wear in the courtroom. Tens of thousands of people set off on a several kilometer path from the seat of the Polish Supreme Court to the complex of parliament buildings. ${ }^{87}$ Judges from several countries, mainly belonging to the European Union, gave their support to Polish colleagues. ${ }^{88}$

The demonstration has contributed to the debate that took place in The Irish Times. According to the editors of that newspaper, the role of judges is not to take

\footnotetext{
${ }^{85}$ K. Sobczak, 'Groźba zawieszenia i 55 zarzutów dla prezesa "Iustitii”', 4 December 2019, 〈https://www.prawo.pl/prawnicy-sady/zarzuty-dyscyplinarne-dla-sedziego-markiewicza-decyzjarzecznika,496352.html $\rangle$, visited 26 September 2020.

${ }^{86}$ See ECtHR judgments: of 26 February 2009, No. 29492/05, Kudeshkina v Russia, 〈http:// hudoc.echr.coe.int/fre?i=001-91501); of 23 June 2016 (GC), No. 20261/12, Baka v Hungary, 〈http://hudoc.echr.coe.int/fre?i=001-163113〉, both visited 26 September 2020; Section 8 of the Basic Principles on the Independence of the Judiciary Adopted by the Seventh United Nations Congress on the Prevention of Crime and the Treatment of Offenders held at Milan from 26 August to 6 September 1985 and endorsed by General Assembly resolutions 40/32 of 29 November 1985 and 40/146 of 13 December 1985, 〈https://www.ohchr.org/en/ professionalinterest/pages/independencejudiciary.aspx $\rangle$, visited 26 September 2020.

${ }^{87}$ ‘Thousands protest against Poland's plan to discipline judges', Reuters, 〈https://www.reuters. com/article/us-poland-judiciary-toga-march/thousands-protest-against-polands-plan-to-disciplinejudges-idUSKBN1ZA0PD $\rangle$, visited 26 September 2020.

${ }^{88 ‘}$ European judges support Polish independent judges, joining the silent march on 11.01.2020 update', 〈https://www.iustitia.pl/en/3588-european-judges-support-polish-independent-judgesjoining-the-silent-march-on-11-01-2020-update), visited 26 September 2020.
} 
part in rallies, even if the organisers emphasise the lack of political goals. The main argument put forward by the author of the editorial comment is that it depriving the judiciary of its credibility. Demonstrating against government policies, especially foreign ones, violates the principle that judges should speak through their judgments. ${ }^{89}$

The editorial position aroused a wave of criticism from the academic community, both in Ireland and Poland. Professors Ronan McCrea (University College, London) and David Kenny (Trinity College, Dublin) argued that judges have every right to defend their independence from political authorities, without which their mission in the state loses its sense; such activities cannot be termed political activities. Furthermore, due to the scale of interconnections between the Member States of the EU, nowadays it is no longer possible to precisely distinguish between the domain of national authorities and the matter of EU law. ${ }^{90}$ Two scholars from the University of Warsaw stated that the 'political' nature of judges' activities should be qualified in the sense of classical Greek philosophy as action in the community of citizens (politeia), and not as participation in the struggle for power. Support for Polish colleagues from the judges of other Member States contributes to the creation of a 'European community of values', in line with the objectives of the Treaty on European Union: an ever closer union of nations based on solidarity. Values that are not defended together cease to be common. ${ }^{91}$

The paradox of this exchange of views is that from some points of view each of the opposing positions can be described as legitimate. The Irish Times editorial is basically correct in saying that judges should speak through their judgments. After all, in modern, law-abiding representative democracies, the belief that the power of judging is separate from both law-making and law enforcement is taken for granted. As already stated, courts have not been called to participate in the normal political process. By exceeding these limits, they would lose their legitimacy to hold control over the legality of actions undertaken by other authorities. The lack of a direct democratic mandate indeed obliges judges to exercise restraint over legislative changes implemented by representative authorities. Outside of the

${ }^{89}$ 'The Irish Times view on Irish judges protesting in Poland: crossing a line, 〈https://www. irishtimes.com/opinion/editorial/the-irish-times-view-on-irish-judges-protesting-in-poland-crossinga-line-1.4134097?fbclid=IwAR1AdLY7DT7q6x4BE0KbmB_leS7XqTdM6L31O_2IZOXhOeW UP4gCOx_Iks4 $\rangle$, visited 26 September 2020.

${ }^{90} \mathrm{R}$. McCrea, 'Irish judges have every right to back protests in Poland', Irish Times, 17 January 2020, 〈https://www.irishtimes.com/opinion/irish-judges-have-every-right-to-back-protestsin-poland-1.4142089 $\rangle$, visited 26 September 2020.

${ }^{91} \mathrm{P}$. Marcisz and J. Urbanik, 'Judges and protests in Poland', Irish Times, 14 January 2020, $\langle$ https://www.irishtimes.com/opinion/letters/judges-and-protests-in-poland-1.4138384〉, visited 26 September 2020. 
province of their usual competence, judges have neither the resources nor the power to actively influence the course of public affairs. ${ }^{92}$

On the other hand, however, what we think is particularly important in the circumstances of the Polish case - defence of the 'inner morality' of law - is a core obligation of the judiciary in a constitutional democracy. There is no doubt that the potential of the despotism of the 'political' authorities, which may feel entitled to arbitrarily influence the sphere of the courts' jurisdiction, as well as to staff the judicial offices according to their will, is much more real than any despotism of the judiciary. Courts subordinate to the executive ${ }^{93}$ lose their identity, becoming only an extension of the police arm of the state; they provide order but do not truly resolve disputes - and in any case society may not believe that they do so. In other words, the lack of independence, just like the attempts to corrupt judges, by definition leads to the deprivation of the third authority of public trust. ${ }^{94}$ This is today's Polish reality.

It would probably be best for judges to limit themselves only to judicial resistance, which would be manifested in the forms of decisions taken in the courtroom. Unfortunately, it is all too probable that the critical voice of judges in the rulings, overwhelmed by intrusive government propaganda, would not be heard by anyone.

Faced with the prospect of such a fundamental change in their mission, Polish judges probably have not only the opportunity, but even the obligation to oppose reforms that undermine their position, even if the legislation appears to accord with the supreme rules of the Constitution. This is what the judges owe to their fellow citizens and - in a sense - to the state whose officers they are. The tragic situation of Polish judges is that their participation in the public debate only becomes possible by crossing the boundaries that are usual in constitutional democracies. It is caused by a state of higher necessity, proportional to the scale of the threat, and thus it becomes justified. Silence would mean consent to the

${ }^{92}$ Cf A. Hamilton, 'The Federalist No. 78: The Judiciary Department', in I. Shapiro (ed.), The Federalist Papers (Yale University Press 2009) p. 391-397.

${ }^{93}$ In order to avoid misunderstandings, it seems noteworthy to emphasise the fact that in some EU countries, especially the Nordic ones, the legal status of judges may be compared to that of specialised governmental functionaries, due to the way judicial careers are managed by administrative bodies, and appointed and controlled by the government. Weak as they might appear in terms of institutional guarantees, such models seem to be acceptable as long as the government neither applies pressure (e.g. rejecting inconvenient candidates for judgesship etc.) nor interferes in the normal course of the administration of justice. For the Swedish model, see J. Bell, 'Sweden's Contribution to Governance of the Judiciary', in M. Andenas and D. Fairgrieve (eds.), Tom Bingham and the Transformation of the Law: A Liber Amicorum (Oxford University Press 2011) p. $84 \mathrm{ff}$.

${ }^{94}$ Clifford Wallace, supra n. 13, p. 244-246; Barak, supra n. 3, p. 77. 
forfeiture of constitutional values, which courts in a democratic state of law may not give up.

\section{CONCLUDING REMARKS}

In 2015, the Polish judiciary stood at a crossroads, facing an unprecedented challenge to its existence in the form of an independent branch of government. The reasons for such a state of affairs are not confined only to the political course adopted in Poland over the past five years. Legitimacy, as a legal characteristic, takes place on a foundation of social legitimation, not the other way round. This is the core of the problem. Thanks to our limited sociological knowledge, we can make a very general hypothesis that Polish society as a whole generally treats public life and state authorities with great distrust. Opinion polls suggest that there is a generalised distrust towards others (consistently around 75\%), and a slightly smaller, but constantly declared percentage of negative responses in surveys about various institutions, such as the Sejm and Senate (53\%), courts $(50 \%)$, and political parties $(63 \%) .{ }^{95}$ Under such circumstances, the populist arguments of the government and MPs of the ruling coalition, some of which we have presented above, do not themselves deprive the courts of their legitimacy: instead they reinforce negative impressions that already exist. When mutual trust is missing from society, the judicial struggle for legitimacy becomes more difficult, entails much extra effort, and - unfortunately - requires time, which is dramatically lacking for Polish democracy.

What should judges do in the face of the global democratic decay that the Polish case is but one example of? The answer to this question remains strongly dependent on the nature of society, its degree of identification with the state and the specific background to the crisis. Since democratic collapse always has its roots in feelings of resentment and a desire to 'regain what has been lost', it is also for the judges to symbolically go back to the sources of the crisis and try to work together to tame and make society aware of the illusions it is being fed by the political class.

Of course, the judiciary's efforts in this direction remain in line with its overall mission of administering justice. Judges speak mainly through their judgments. Still, outside the courtroom the judge is also a citizen and has the right and even the duty to defend the value of the legal system. Of course, judges should also prove the value of their words through deeds - by improving the quality of their

\footnotetext{
${ }^{95}$ As evidenced by the results of public opinion polls conducted in 2018 by one of the leading Polish analytical centers, Centrum Badania Opinii Spotecznej (abbrev. CBOS - the Public Opinion Research Center); $f$ CBOS, O nieufności i zaufaniu, 〈https://www.cbos.pl/SPISKOM.POL/2018/ K_035_18.PDF), visited 26 September 2020.
} 
decisions, reporting motives of their judgments in a way that is readable for parties and the public, working to improve the dignity of their office and convincing fellow citizens in the courtroom and outside that the rule of law as a basic value of constitutional democracy, has no party colours and is intended to serve everyone, regardless of their beliefs and convictions. For those, however, who act under threat of being punished for simple judicial activities, in an indifferent society, it still may not be enough. Due to their knowledge and education, judges can play a very positive role in the legal education of society. Hence they can and should publish and speak out in the press and social media. No one is entitled to prohibit them from criticising lawmaking and corruption.

This is the role of Polish judges today. Due to some historical reasons explained at the start of this article, law appears an odd thing to a large part of our society; attitudes of legal nihilism are very common. It would be an illusion to believe that such attitudes might be changed in the short term. It is, rather, a task for years, requiring much patience and persistence. Nevertheless, judges should undertake this work. They have no other choice. 